\title{
Corporate Governance Intelligence: Minority Shareholder's Aspects (Evidence From Ukraine)
}

\author{
Tetiana Momot, Oleksandr Vashchenko, Nina Avanesova, Anna Chudopal \\ O.M. Beketov National University of Urban Economy, Kharkiv, Ukraine
}

\begin{abstract}
The paper is devoted to the corporate governance intelligence system investigation as the part of the complex stakeholder-related approach to the corporate strategic intelligence system (CSIS). The special attention is given to the minority shareholders activism in the system of corporate governance. Some existing methods of abusing minority shareholders rights, made by joint-stock companies executives, are generalized. The recommendations for minority shareholder's rights protection are given. The necessity for the implementation of the stakeholders-oriented approach for the CSIS creation on the base of companies' security principles is substantiated.

Keywords: corporate governance intelligence, minority shareholders rights, corporate governance, financial and economic security system, corporate strategic intelligence
\end{abstract}

\section{Introduction}

The need for corporate governance intelligence arises from the potential conflicts of interests among stakeholders in the corporate structure. These conflicts of interests (agency problems) arise from two main sources. Firstly, different stakeholders have different goals and preferences. Secondly, the stakeholders have imperfect information as to each others' actions, knowledge, and preferences.

The ownership structure in Ukraine was formed under condition of mass privatization which is caused the great number of small shareholders' appearance. At the beginning of 1992, nearly 17 million of Ukrainians — one third of the country population — own shares of 35 thousand national joint-stock companies. Minority shareholders did not know their own rights and could not protect their rights in accordance with the law. Corporate management staff let abuses happen, which are also provoked by shareholders' legal irresponsibility and lack of law defense. Moreover, in a highly diffuse ownership structure, there is no incentive for any owner to monitor corporate management. In condition, when security market did not work and the market share value was not determined, small shareholders sold their shares namely to corporate management. Under such conditions, the Ukrainian oligarchic system was developed and during Leonid Kuchma's second presidential term took its final form. In 2014, the combined wealth of Ukraine's 50 richest oligarchs is equal to $85 \%$ of Ukraine's GDP. The total worth of the wealthiest 50 Ukrainians is $\$ 112.7$ billion, as much as two annual Ukrainian state budgets. Furthermore, according to Holoyda (2013), 100 individuals represented the

Tetiana Momot, Ph.D. in economics, professor, O.M. Beketov National University of Urban Economy, Kharkiv, Ukraine. Oleksandr Vashchenko, Ph.D., associate professor, O.M. Beketov National University of Urban Economy, Kharkiv, Ukraine. Nina Avanesova, Ph.D., associate professor, O.M. Beketov National University of Urban Economy, Kharkiv, Ukraine. Anna Chudopal, post-graduate student, O.M. Beketov National University of Urban Economy, Kharkiv, Ukraine.

Correspondence concerning this article should be addressed to Tetiana Momot, vul. Revolucii, 12, Kharkiv, 61002, Ukraine. E-mail: tvmomot@gmail.com. 
"oligarchs" and "family" or $0.00003 \%$ of the total population control $80 \%-85 \%$ of Ukraine's GDP/wealth. Out of the 1,645 billionaires followed by Forbes in 2014, nine are from Ukraine (Holoyda, 2013).

Current corporate environment in Ukraine is characterized with the high level of corruption, especially in light of the deepening socio-political and financial-economic crisis in the country, which poses a serious threat to the national security of Ukraine. The results of a survey of 84 Ukrainian senior executives and managers representing 18 industries (Price Waterhouse Coopers, 2011) reveal that economic crime in Ukraine is characterized as follows:

- Thirty-six percent of organizations had experienced economic crime in the past 12 months;

- Every third organization does not perform risk assessments;

- Assets misappropriation (73\%) and bribery and corruption (60\%) remain the most common types of economic crime in Ukraine;

- The amount of internal fraud has increased significantly (by 22\%) since 2009;

- The majority of Ukrainian respondents who suffered economic crime estimated losses up to five million dollars;

- Forty percent of economic crimes are committed by senior management;

- One out of five organizations that have suffered from economic crime has not taken any actions against an internal perpetrator of fraud.

The extent of criminalization and corruption in government has reached a critical point which challenges the legitimacy of government and threatens it with the collapse of public institutions and the termination of democratic state development. Fraud is now viewed as an inherent feature of doing business in Ukraine, which leads companies down a path where the companies themselves provide a rational for potential fraudsters, and therefore increase the probability of fraud. Economic crimes threaten the basic processes common to all business - paying and collecting, buying and selling, growing and expending, and sourcing and supply chain. Thus, one of the key fraud prevention techniques is for businesses to know who with whom is doing business.

In condition of implementation of the association agreement between Ukraine and the European Union, the development of the scientific systemic approach to control and prevent economic crime by creating clear EU standards in the areas of anticorruption and good corporate governance is based on a transparent intelligence system.

Taking into account all mentioned above, it is vitally important to create a system of corporate governance intelligence, in order to provide the high level of financial and economic security in the complex corporate environment.

Recent research has viewed the concept of corporate governance in different ways. Monks and Minow (1995) presented the corporate governance as the relationship among various participants (chief executive officer, management, shareholders, and employees) in determining the direction and performance of corporations. Gillan and Starks (1998) defined corporate governance as the system of laws, rules, and factors that control operations at the company. A firm's governance, as they said, comprises the set of structures that provide boundaries for the firm's operations. This set of structures includes participants in corporate activities, such as managers, workers, and suppliers of capital; the returns to those participants; and the constraints under which they operate. La Porta, Lopez-de-Silanes, Shleifer, and Vishny (1997) and Shleifer and Vishny (1997) 
defined corporate governance in terms of the economic interests of the participants. In particular, they refer to corporate governance as dealing "...with the ways in which suppliers of finance to corporations assure themselves of getting a return on their investment". The Organization for Economic Co-operation and Development (2004) defined corporate governance as a set of relationships among a company's board, its shareholders, and other stakeholders. It also provides the structure through which the objectives of the company are set, the means of attaining those objectives, and monitoring performance are determined. Corporate governance as the system by which companies are directed and managed is presented in Australian Stock Exchange (ASX) Principles of Good Corporate Governance and Best Practices Recommendations (Retrieved from http://www.asx.com.au/documents/asx-compliance/principles-and-recommendations-march-2003.pdf). It influences how the objectives of the company are set and achieved, how risk is monitored and assessed, and how performance is optimized. Good corporate governance structures encourage companies to create value and provide accountability and control systems commensurate with the risks involved. Fidrmuc, Goergen, and Renneboog (2006) determined the corporate governance system as the combination of mechanisms which ensure that the management (the agent) runs the firm for the benefit of one or several stakeholders (principals). Such stakeholders may cover shareholders, creditors, suppliers, clients, employees, and other parties with whom the firm conducts its business. In accordance with Goergen, Brewster, and Wood (2012), corporate governance deals with the conflicts of interests between the providers of finance and the managers; the shareholders and the stakeholders; different types of shareholders (mainly the large shareholder and the minority shareholders); and the prevention or mitigation of these conflicts of interests. Kristie (2013) emphasized that corporate governance is gathering together a group of smart, accomplished people around a board table to make good decisions on behalf of the company and its stakeholders.

Generally, corporate governance refers to the host of legal and non-legal principles and practices affecting control of publicly held business corporations. Most broadly, corporate governance affects not only who controls publicly traded corporations and for what purpose but also the allocation of risks and returns from the firm's activities among the various participants in the firm, including stockholders and managers as well as creditors, employees, customers, and even communities.

Thus, in highly competitive global markets, a well-run corporate governance intelligence system (CGIS) can forge information links in the corporate governance system and help to achieve the quality corporate goals and to support the corporate reputation.

Against this background, this study investigates the impact of shareholders' activism on the corporate governance in Ukraine over the period 2000 through 2014.

\section{Objectives and Methodology}

Strategic intelligence pertains to the following system of abilities (Thomson Reuters Corporate Governance Intelligence, 2013):

- foresight - the ability to understand trends that present threats or opportunities for corporation;

- visioning - the ability to conceptualize an ideal future state based on foresight and create a process to engage others to implement it;

- system thinking - the ability to perceive, synthesize, and integrate elements that function as a whole to achieve a common purpose; 
- motivating - the ability to motivate different people to work together to implement a vision. Understanding what motivates people is based upon another ability, personality intelligence;

- partnering - the ability to develop strategic alliances with individuals, groups and organizations. This quality also depends on personality intelligence.

Today's economic environment demands that enterprises in both the public and private sectors reach beyond traditional boundaries. Citizens, customers, educators, suppliers, investors, and other partners are all demanding better custodianship of their information and more access to strategic resources. As enterprises rise to meet this demand, traditional boundaries are disappearing and the premium on information security is rising. Heightened concerns about critical infrastructure protection and national homeland security are accelerating this trend. (Shillabeer, Buss, \& Rousseau, 2011, p. 11)

Thus, the complex stakeholder based approach should be implemented for the corporate intelligent system development. In accordance with approach suggested by authors, the stakeholder based CGIS is the preferred system for planning, collecting, processing, analysis, dissemination, and use of intelligence information which is required for market threats. CGIS includes the following subsystems (in accordance with the groups of key stockholders) (Corporate Governance Task Force, 2004; Fuld, 2005; Kahaner, 2006):

(1) External intelligence:

- public sector: government/policymakers/society (global, national, regional, and local) intelligence;

- competitor intelligence;

- customer intelligence;

- supplier intelligence;

- investor intelligence;

- business partner intelligence: creditors, project partners;

(2) Internal intelligence:

- employee intelligence;

- board of directors intelligence and managers intelligence (managing director or chief executive officer (CEO));

- shareholders intelligence.

Corporate governance intelligence is never meant to be a one-shot activity; as the company changes, so will its intelligence needs. The fundamental mission of CGIS is to provide intelligence to support intelligence corporate decisions. A well-run intelligence program can forge information links in the corporate governance system and help to achieve the quality corporate goals (see Table 1).

Corporate governance intelligence is determined as the subsystem of planning, collecting, processing, analysis, dissemination, and use of corporate governance information which is required for corporate governance quality evaluation. The emphasis is given to minority shareholders' problems. It is not taken into account that developing and improvement of the corporate system have to be provided from the inside (specific programs for managers) and from the outside - the large number of responsible minority shareholders forming. It is experienced owner, who is going to stimulate joint stock company (JSC) to protect investors' rights, to create stable mechanisms of governing and control and to act openly.

The purpose of this study is to reveal, generalize, and make public some existing methods of abusing, made by joint-stock companies' executives, so as to increase the effectiveness of the corporate sector's activity in Ukraine and to work out specific recommendations on plain governing of JSC by its owners-shareholders. 
Methodical basis of research are the methods of complex, system, and comparing analysis. The main object of research is the sample of 20 industrial joint-stock companies in Kharkiv region. The main issue is the relationships between executives and minority shareholders on their equal rights' realization. The new approach is formed by making direct contact with the executives from the name of shareholders.

Table 1

CGIS Subsystems: Stakeholders-Oriented Approach Implementation

\begin{tabular}{|c|c|}
\hline CGIS subsystems (groups of stakeholders) & Objectives \\
\hline $\begin{array}{l}\text { Public sector: government/policymakers/society } \\
\text { (global, national, regional, and local) intelligence }\end{array}$ & $\begin{array}{l}\text { to monitor government's policy and its influence on the corporate security } \\
\text { level }\end{array}$ \\
\hline Competitor intelligence & $\begin{array}{l}\text { to monitor current and potential competitors; to study brand excellence } \\
\text { model with the emphasis on the following focus areas: brand equity, } \\
\text { involvement, and price/value }\end{array}$ \\
\hline Customer intelligence & $\begin{array}{l}\text { to reveal emerging technologies, competitive advantages and } \\
\text { disadvantages, new product ideas; to determine focus group and their exact } \\
\text { needs, to study customer satisfaction and loyalty by measuring the effect of } \\
\text { the five factors: products, supply, employees, sales, and after-sales service }\end{array}$ \\
\hline Suppliers intelligence & $\begin{array}{l}\text { to reveal suppliers accuracy and quality data, redundancy, ownership, and } \\
\text { diversity certification data; to identify diverse supplier risk for the } \\
\text { supply-chain optimization }\end{array}$ \\
\hline Investor intelligence & $\begin{array}{l}\text { to study the potential investors by using stock signals, index analysis, and } \\
\text { market timing indicators }\end{array}$ \\
\hline Employees intelligence & $\begin{array}{l}\text { to study employee job satisfaction, loyalty, motivation, and well-being at } \\
\text { work by measuring the following seven parameters: image, general } \\
\text { management, line manager, teamwork, daily work, salary and working } \\
\text { conditions, and professional and personal development }\end{array}$ \\
\hline $\begin{array}{l}\text { Board of directors intelligence managers intelligence } \\
\text { (managing director or chief executive officer (CEO)) }\end{array}$ & $\begin{array}{l}\text { to estimate the level of board of directors independence from CEO; to study } \\
\text { board of directors policy of hiring and firing of top corporate management; } \\
\text { to study top manager's needs, skills of management- from hiring, firing, } \\
\text { and training employees to negotiating with others, facilitating meetings, and } \\
\text { moving career ahead; the abilities to control the resources and expenditures } \\
\text { of the corporation; to gain profit }\end{array}$ \\
\hline Shareholders intelligence & $\begin{array}{l}\text { to study owner's satisfaction and loyalty by measuring the effect of } \\
\text { dividend policy, the structure, and cost of ownership }\end{array}$ \\
\hline
\end{tabular}

\section{Results}

The summary of the most spread shareholders legal rights' and interests' abuses, while JSC activity looks like the following:

- limited access to the company information for shareholders;

- breaking the terms of handing in and making public the information about the general meeting of shareholders;

- inadequate providing of complete and real information about the JSC activity;

- unsatisfactory level of participation in making decisions on assets disposal;

- unsatisfactory level of participation in controlling of significant amounts contracts;

- making difficult for small shareholders to enter supervisory board;

- insufficient opportunity for small investors to influence forming of the general meeting agenda;

- divided policy issues.

According to the suggested approach, there was a testing of general year's meeting of shareholder's procedures by taking part in the meetings (using warrants from the real shareholders). The results are given in Figure 1. 


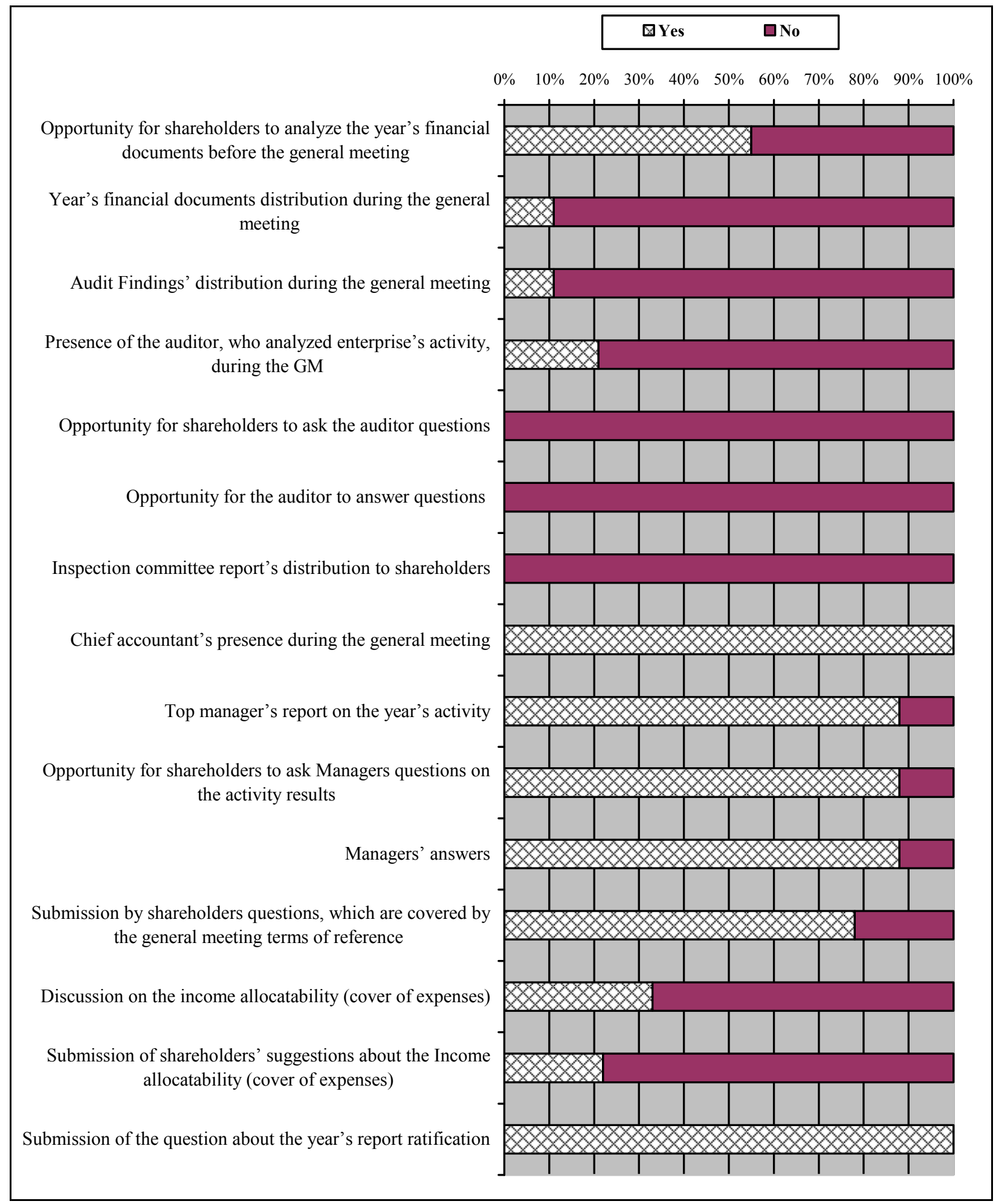

Figure 1. Testing results of the general meeting procedure.

In order to study the official documentation of companies, shareholders sent letters of request to the executives. Testing results show that in $55.5 \%$ of situations, shareholders did not get the year's financial reports before the general meeting. 
Sometimes, when shareholders had the chance to get the needed information, they mostly were to make writing outs from given documents on the last day before the general meeting.

There were only two times, when shareholders were given copies of the documents in time. Even then their request to learn the contents of the charter and general regulations was declined.

At the best, shareholders could have the old wordings of the charter or just some model forms.

In this context appeal against the executives on different kinds of information, concealing should be realized in court.

Nevertheless, there are a lot of examples, when the executives ignore minority shareholders' rights on getting the whole information about the enterprise.

As a result, minority shareholders have not been able to realize their own rights effectively during the general meeting, or got the chance to learn the information about the problems, which had to be solved during the general meeting.

There are also shareholders' rights abusing in cases of assets operations, such as, transferring, selling at the lowest cost, and using of credits without purpose.

The important thing is that modern Ukrainian corporate technologies do not insure equal possibilities to get the information for all shareholders; they are still legally imperfect and not plain enough. These are the reasons for shareholders to make decisions of destructive character.

\section{Discussion}

Unfortunately, many people are simply repulsed from the stock market activities, because financial documents are not transparent and there are a lot of abuses in the corporate relationships.

In order to estimate the quality of financial reports, specialists of "intensive technologies in microeconomics foundation" have questioned financial directors and chief accountants. As a result, they received very uneasy information about unsatisfactory authenticity level of enterprises' financial reports: Forty-five percent of financial managers do not think that those reports are reliable. More than $80 \%$ of chief accountants have manipulated the working information in this or that way. Even more, the "receivers" of these reports have been determined. Financial staff named the following groups of people, to whom they have given the false information:

- in 33\% of cases, to creditors (banks, suppliers, etc.);

- in $50 \%$ of cases, to the government bodies;

- in $17 \%$ of cases, to the owners.

In conclusion, it has to be mentioned that:

(1) Most of minority shareholders in Ukraine are still titular owners. They are not educated in economical questions and not protected by the law. Clearly, this situation does not stimulate the development of effective and transparent corporate governing by shareholders;

(2) Minority shareholders rights and legal interests infringement by the executives are wide spread, while joint-stock companies work in unqualitative conditions;

(3) Shadow economy has a negative influence on investment development of joint-stock companies. Income minimizing restricts the dividend's amount and does not favor the growth of stocks' price. This fact, in its turn, does not let people invest their money in shares and does not provide effective stock market functioning; 
(4) Unsatisfactory level of financial documents authenticity influences badly the investment decision making not only for shareholders, but also for the future investors;

(5) Low level of the corporate culture does not contribute to the balanced corporate relationships.

Thus, the most topical problems in the corporate governing today in Ukraine to form the corporate ethic rules in accordance with the European standards (corporate governance guidelines, code of business conduct and ethics) help to ensure legal regulation and the balance of stakeholder's interests.

Transparent functioning of the corporate sector will increase its competitiveness and economic effectiveness. Besides, corporate governing improvement is going to be an important step on the way to attractive investment conditions creating. It will guarantee the social effect that will make the national economy more competitive.

\section{Conclusions}

CGIS presents a potentially powerful tool for the analysis of the different groups of stakeholders and permits to create a corporate intelligence network and information economics measurements databases with the aim to adopt strategic decision making.

The company must select and institutionalize broad corporate security principles to fully protect stakeholder interests. Enacted principles inform decisions thereby influencing strategies, plans, and policies. These actions create a culture of security throughout the company. Enterprise security principles are required to protect stakeholder interests include: accountability, adequacy, awareness, compliance, effectiveness, ethics, inclusion, individual, equity, information, sharing, measurement, perspective/scope, response, and risk management.

The implementation of the stakeholders-oriented approach for the CSIS creation on the base of enterprise security principles will permit:

- to evaluate the corporate security on the regular base; to review the evaluation results with stakeholders as appropriate; and to report on performance to the governing body, including a plan for remedial action to address any deficiencies;

- to identify the most important focus areas the company's brand and place it in relation to selected competitors in specific segments;

- to identify which initiatives to use to improve or maintain customer satisfaction and strengthen the development of corporation; to retain current customers and attract new customers;

- to optimize corporate supply chain;

- to identify management problem and to improve the corporate governance system;

- to identify the areas in which corporation can start initiatives to maintain or improve job satisfaction and strengthen development; to develop employee position descriptions define security roles, responsibilities, skills, certifications, and agreements to comply with security policy;

- to improve the dividend policy and to attract new investors;

- to compare the investment in company security protection strategies (principles, policies, procedures, processes, and controls) with risk. Determination of risk is based on the value, sensitivity, and criticality of the asset with respect to its vulnerability to loss, damage, disclosure, or denied/interrupted access. Probability, frequency, and severity of potential vulnerabilities are considered along with a comparison of the cost to reconstitute the asset versus the cost to protect it; 
- to review, assess, and modify corporate security protection strategies in response to the dynamically changing risk environment in which it operates;

- to use the information, systems, and networks across an enterprise and by all stakeholders matches expectations established by social norms, obligations, being a responsible internet citizen, and enterprise codes of ethical conduct.

\section{References}

Australian Stock Exchange. (2003). Australian stock exchange (ASX) principles of good corporate governance and best practices recommendations. $\quad$ Retrieved from http://www.asx.com.au/documents/asx-compliance/principles-and-recommendations-march-2003.pdf

Corporate Governance Task Force. (2004). Information security governance: A call to action. Retrieved from http://www.dhs.gov/sites/default/files/publications/csd-informationsecuritygovernance-acalltoaction-2004.pdf

Fidrmuc, J., Goergen, M., \& Renneboog, L. (2006). Insider trading, news releases and ownership concentration. Journal of Finance, 61(6), 2931-2973.

Fuld, L. (2005). The new competitor intelligence. The complete resource for finding, analyzing, and using information about your competitors. New York: John Wiley \& Sons, Inc.

Gillan, S. L., \& Starks, L. T. (1998). A survey of shareholder activism: Motivation and empirical evidence. Contemporary Finance Digest, 2(3), 10-34.

Goergen, M., Brewster, C., \& Wood, G. (2012). Varieties of capitalism and investments in human capital. Wilkinson Industrial Relations: A Journal of Economy and Society, 51(1), 501-527.

Holoyda, O. (2013). Ukrainian oligarchs and the "family", a new generation of czars-Or hope for the middle class? Retrieved from http://www.irex.org/sites/default/files/Holoyda\%20EPS\%20Research\%20Brief.pdf

Kahaner, L. (2006). Competitive intelligence: How to gather, analyze, and use information to move your business to the top. New York: Simon \& Schuster.

Kristie, J. (2013). Corporate governance of shoppers stop. Retrieved from http://ru.scribd.com/doc/215893431/corporate-governance-of-shoppers-stop\#scribd

La Porta, R., Lopez-de-Silanes, F., Shleifer, A., \& Vishny, R. (1997). Legal determinants of external finance. Journal of Finance, 52(3), 1131-1150.

Monks, R., \& Minow, N. (1995). Corporate governance. Cambridge: Blackwell.

Organization for Economic Co-operation and Development. (2004). Organization for Economic Co-operation and Development publications service. Retrieved from http://www.oecd.org/daf/ca/corporategovernanceprinciples/31557724.pdf

Price Waterhouse Coopers. (2011). Ukraine global economic crime survey. Retrieved from http://www.pwc.com/en_UA/ua/press-room/assets/GECS_Ukraine_en.pdf

Shillabeer, A., Buss, T. F., \& Rousseau, D. M. (2011). Evidence-based public management: Practices, issues, and prospects. New York: M.E. Sharp, Inc.

Shleifer, A., \& Vishny, R. (1997). A survey of corporate governance. Journal of Finance, 52(2), 737-775.

Thomson Reuters Corporate Governance Intelligence. (2013). Corporate governance intelligence. Retrieved from $\mathrm{http} / / /$ dmi.thomsonreuters.com/Content/Files/Full_Year_2013_Thomson_Reuters_Corporate_Governance_Intelligence.pdf 